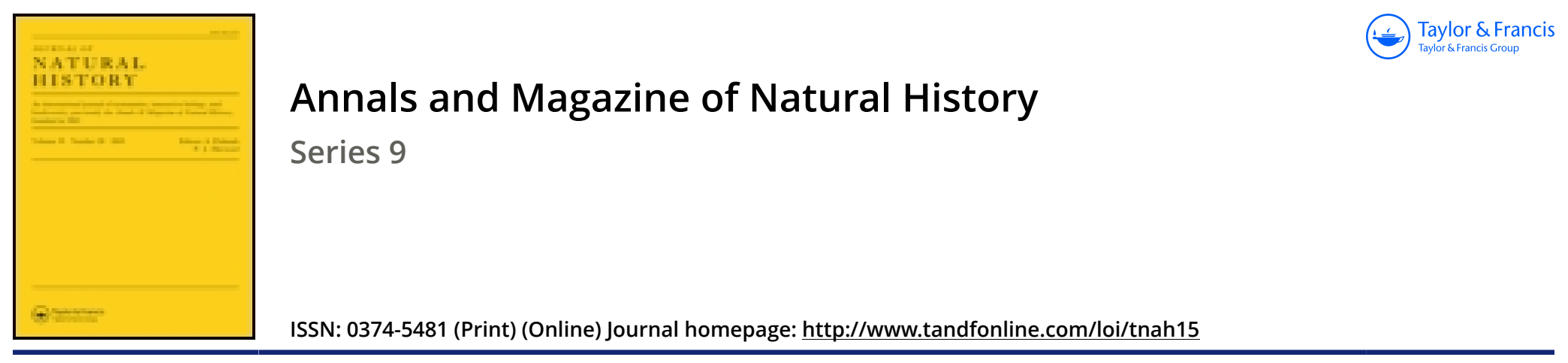

\title{
I.-Fossil Arthropods in the British Museum.-V. Oligocene Hymenoptera from the Isle of Wight
}

\section{T.D.A. Cockerell}

To cite this article: T.D.A. Cockerell (1921) I._Fossil Arthropods in the British Museum.-V. Oligocene Hymenoptera from the Isle of Wight , Annals and Magazine of Natural History, 7:37, 1-25, DOI: $10.1080 / 00222932108632485$

To link to this article: http://dx.doi.org/10.1080/00222932108632485

Published online: 02 Sep 2009.

Submit your article to this journal $\sqsubset$

Џ Article views: 2

Q View related articles ¿

7 Citing articles: 5 View citing articles 5 


\title{
'THE A N N A LS
}

\section{MAGAZINE OF NA'TURAL IISTORY.}

[NINTH SERIES.]

\author{
“................ per litora sparyite muscum, \\ Naiades, et circum vitreos considite fontes: \\ Pollice virgineo teneros hic carpite flores: \\ Floribus et pictum, dive, replete canistrum. \\ At vos, o Nymphæ Craterides, ite sub undas; \\ Ite, recurvato variata corallia trunoo \\ Vellite muscosis e rupibus, et mihi conchas \\ Ferte, Dex pelugi, et pingai conchylia succo." \\ N. Parthenii Giannettaxi, Iol. 1.
}

No. 37. JANUARY 1921.

I.-Fossil Arthropods in the British Museum.-V. Oligocene IIymenoptera from the Iste of Wight. By 'T. D. A. Cockereld, University of Colorado*.

ThE British Museum contains a very large collection of fossil insects from the Oligocene of Gurnet or Gurnard Bay, in the Isle of Wight. 'These are labelled as coming from two sources, the Brodie and A'Court Smith collections. 'The Rev. P. B. Brodie, in his account of the Is'e of Wight insect beds published by the Warwickshire Naturalists' and Archæologists' Field (jub in 1878, say's :-

"I am indebted to Mr. A'Court Smith for specimens kindly presented to me, and for others in exchange, and for an account of the strata from which they were procured and other particulars connected with them. By his long residence in the Isle of Wight, and diligent search for the fossils of the district, he has acquired an intimate knowledge of the geology, and obtained the first and largest collection of British Tertiary fossil Insects yet recorded."

* I am greatly indebted to Dr. A. S. Woodward for permission to study the British II useum series, and for facilities at the Museum.

Ann. \& Mag. N. Hist. Ser. 9. Vol. vii. 
It is thus evident that the Brodie specimens are from the same source as the others. In one case a specimen (In. 17,2:7) from the A'Court Smith collection proves to be the reverse impression of one (1.9387) obtained from Brodie.

The specimens labelled as from E. J. A'Court Smith were purchased in 1883, but a large collection remained in Mr. A'Court Smith's possession, and after his death was put up at auction. Very fortunately it fell into good hands, coming into the possession of Mr. R. W. Hooley. $\mathrm{Mr}$. Hooley has been good enough to send his collection to the British Museum to be worked up with the other materials. It includes not only the A'Court Smith series, but also specimens collected by himself.

On sorting ont all these materials, it is found that the specimens tit for description constitute only a small minority. Yet the others have a certain value, as their general character can usually be recognised, and thus the total absence of a number of families and genera now common in Lurope becomes more striking. Anong the Diptera, for instance, Culicidæe, Tipulidæ, Psychodidæ, Mycetophilidæ, Bibionidæ, Stratiomyidæe, and small acalyptrate Muscoids are largely represented. A few specimens represent Asilidx, Bombyliidæ (Systropus), Chironomidæ, Leptidæ, and Rhyphida, but numerous families which might be expected are absent. It is obvious that the collections are by no means fully representative of the Oligocene insect fauna of Britain ; they represent in the main a water-side fauna, that of a moist semi-aquatic lowland, with many species breeding in the water. 'I'he upland inseets, and especially the anthophilous forms, are not preserved. It is important to realise this, as otherwise it might be inferred that anthophilous insects were rare or absent in Oligocene times. The rather numerous bees from Baltic amber show that this was not really the case, and indeed the amber also contains a number of beautifully preserved flowers.

Among the Hymenoptera preserved at Gurvet Bay, we fiud vast numbers of ants, of comparatively few species, and many parasitic forms, nearly all the specimens representing different species. There are also a few wasps of different fimilies, and some cynipids which should have fed on the oak and the rose. lin dealing with the Ichneumonidæ and Braconirlar, 1 have rarely been able to feel quite confident of the generic assignments. The species have an extremely modern and conmonplace appearance, but on comparing them with living suecies, they usually differ in a number of details. The bees in Baltic amber are all of extinet genera, 
but the ants include both extinct and modern types, a few hardly separable as species from these still living. There is thus a rather strong probability that many of the Oligocene Ichneumonids do really represent extinct genera, but the evidence is not so complete and satisfactory as we could wish. We have to depend almost wholly on the venation, and some of the modern genera, as geuerally understood, show a wide range of variation in wing-characters. To take an extreme case, the Braconid or Alysiid genus Dacnusa contains species so diverse that Foerster proposed to divide it into 14 genera. Dacnusa or Phanolexis petiolata, Nees, is extraordinarily different in venation from $D$. or Agonia adducta, Hal. If these were found fossil, we should certainly place them in different genera, assuming (contrary to the actual facts) that wings so diverse must belong to very distinct sorts of insects. Thus the matter is full of uncertainties, as it stands at present, and it would be possible to defeud the proposal of several more generic names, or the other extreme of none at all. It must be said, however, that the fossils were compared with all the figures in Morley's works on the British and Indiau Ichneumonida, and with those in Marshall's writings on the Braconidie, and other publications, and with very numerous specimens in the Museum collections, so that in some cases the failure to find a satisfactory modern analogue created a strong presumption in favour of an extinct genus.

H Y M E N O P T E R A.

Key to Gurnet Bry Ichneumonidx*.

Areolet present ............... 1.

Areolet itbseut $\ldots \ldots \ldots \ldots \ldots \ldots$. 6.

1. Areolet distinctly pentagonal (Cryp-

tines or Ichnemonines) .......... 2.

Areolet not jentagonal (Pimplines,

'Tryphonines, or Ophioniues) $\dagger \ldots . .3$.

* Abbreviations used in lieys and descriptions :-Maryinal or radial cell, m.; first division of radius (radial cell on first submarginal), r. 1 ; second division of radius, r. L2; stigma, st. ; areolet, ar. ; submarginal cell, s.m. (only closed cells counted, so that two cells are recognised where some anthors recognise three); basal nervure, b. n. ; transverse median nervure, t.-m.; transverse cubital nervure, t.-c. ; recurrent nervures, r. n. 1 , r. n. 2 ; discoidal cells, disc. $1,2,3$; combined first submarginal and first discoidal cells, smd.; B.M., British Museum collection; H., R. W. Hooley collection; B., Brodie collection; A'C. Sm., A'Court Smith.

$\dagger$ Orthocentrus (Tryphonine) has the areolet pentigonal, but is not like any of the fossils. Elrisa, Cameron (Ophionine), is described as having areolet pentagonal, but Mr. Morley has made a pencilled marorinal note at the B.M. that it is quadrate in the type. II $\theta$ also notes that the spiracles are exactly circulirr. 
2. R. n. 1 nearly straight

R. n. 1 strongly curved ...........

3. Stigma greatly elongated, not trigonal; ar. small ..............

Stigma trigonal .............

4. B. n. going far basad of t.-m.; r. 1

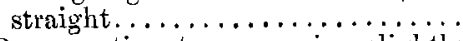

B. n. meeting t.-m, or going slightly basad ; r. 1 curved ..............

5. A stump of a vein on r. n. 1, representing limit of disc. $1 \ldots \ldots \ldots$.

No such stump of a vein .........

6. T.-m. vertical, in line with lower part of b. n.; abdomen long-petiolate .. T.-m. oblique, or not in line with b. $n$.

7. Radial nervure curved, not angled at t.-c.; b. n. meeting t.-m. ........

Radial nervure angled at t.-c. ......

8. Marginal cell deep............. Polysphincta atavina, sp. n.

Marginal cell lanceolate ......... Lampronota disinita, sp. n.

9. B.n. curved $\ldots \ldots \ldots \ldots \ldots \ldots \ldots$ Polyctistacs anglicus, sp. n.

B. n. nearly straight .......... Acumtia perplex $a, \mathrm{~s} . \mathrm{n}$.

On comparing the Florissant (Miocene) Hymenoptera described by Brues(Bull. Mus. Comp. Zool., 1910) the following points of interest appear. Trogus vetus runs in the above table to the Coleocentrus, which it rather closely resembles. Six species of Ichneumon figured by Brues all have the areolet more constricted above than $I$. acourti. Hemiteles priscus runs in the table to Acourtia, which it resembles in the very oblique t.-m., but the shape of smd. is quite different. Cryptus delinealus has the areolet much like that of the Stilpnus, but otherwise differs. Protohellwigia, Brues, has no ally among our fossils. Hiatensor, Brues, runs in the table to Acourtia, but differs at once in the slender stigma and long narrow disc. 3. Exetastes inveteratus resembles Lithapechtis in many respects, but the stigna is much larger and disc. 3 shorter in the Florissant fossil. Mesochorus lapideus also resembles Lithapechtis, but the b. n. meets t.-m. The areolet is like that of several of the fossil species of Mesochorus.

\section{Stilpnus oligocenus, sp. n. (Fig. 1.)}

Thorax black. Anterior wing nearly $3 \mathrm{~mm}$. long, pale ferruginous, with red-brown stigma and nervures; st. large, m. deep, the radial nervure curved, not angled; b, n. meeting the oblique t.-m., which is somewhat arched outward; 
areolet large, nearly equilaterally pentagonal, the lower apical side largest; smol broad at end.

H. 834. Very similar to the living S. gagates, Grav.

Fig. 1.

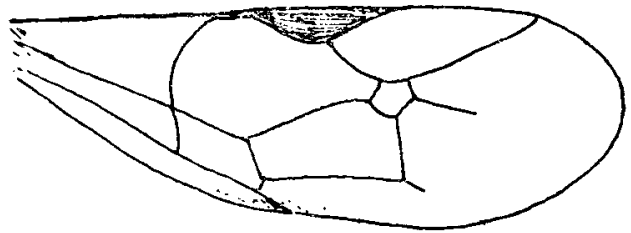

Stilynus oligocenus, sp. $\mathrm{n}$.

Ichneumon (s. latiss.) acourti, sp. n. (Fig. 2.)

Abdomen petiolate. Anterior wing about $5 \mathrm{~mm}$. long, greyish luteous, with deep ferruginons veins. Stigma trigonal, the two lower faces about equal ; marginal cell deep, and not very long ; areolet pentagonal, exactly as in

Fig. 2.
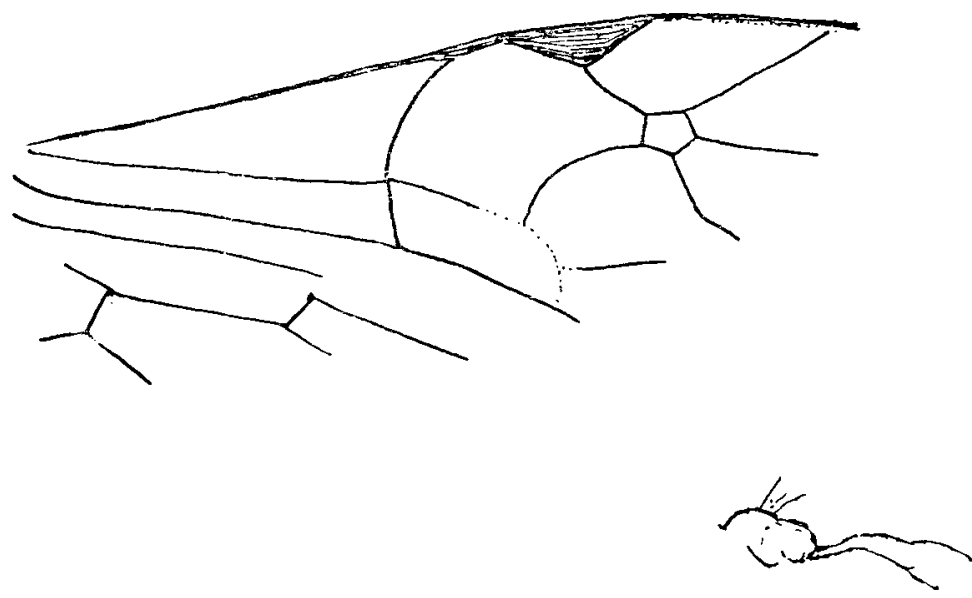

Ichneumon (s. latiss.) acourti, sp. $\mathrm{n}$.

Coelichneumon impressor, Zett. ; b. n. strongly curved, infuscated, meeting t.-m. a little to the basad side; t.-m. oblique, the lower side more apicad. 
II. 1520. This may be a Cryptine; thus Holocryplus has a similar arcolet, but the b. $n$. is straight, except for a bend at the lower end. Pycnocryptus exactly agrecs in the areolet, and the hind wing agrees, but the b. $\mathrm{n}$. is straight.

\section{Coleocentrus gurnetensis, sp. n. (Fig. 3.)}

Thorax black. Anterior wing about $10.5 \mathrm{~mm}$., marginal cell $4 \mathrm{~mm}$. long; wing hyaline, with broad pale ferruginous clouds along veins and in apical part of marginal cell (as preserved); stigma and nervures piceous; areolet very small, triangular, petiolate above; stigma long and narrow; b.n. straight, going basad of the oblique t.-m.

Fig. 3.

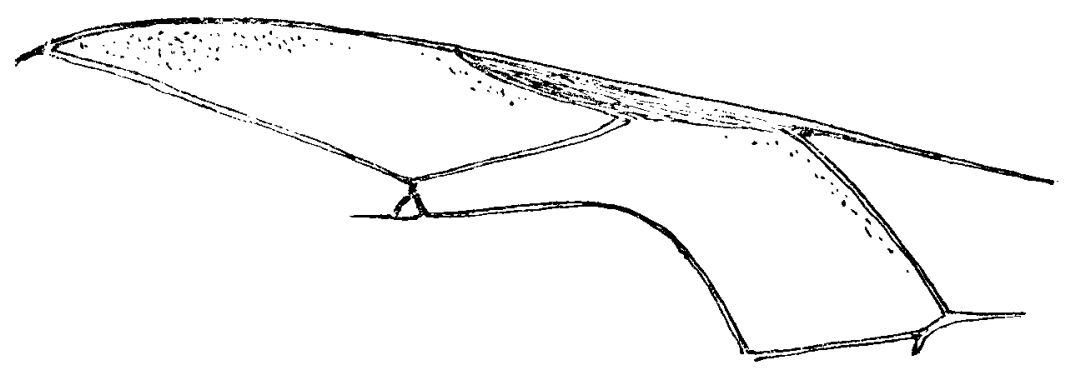

Coleocentrus gurnetensis, sp. n.

B.M., In. $17079\left(\mathrm{~A}^{\circ} \mathrm{C}\right.$. Sm.). The venation agrees very well with that of the much larger $C$. excitator, Poda; the size of the fossil nearly agrees with $C$. caligatus, Grav. At first I thought this might be a Campoplex, but the narginal cell aud small areolet agree better with Coleocentrus. There is some resemblance to Rhyssa, but that has $r .2$ conspicuously arched.

\section{Lithapechtis (gen. nov.) fumosus, sp. n. (Fig. 4.)}

Anterior wing slightly over $6.5 \mathrm{~mm}$. long, fuliginous, with fuscous nervures and ferruginous stigma. Stigma well developed; marginal cell deep, trigonal, the lower sides straight, with a strong angle at t.-c.; areolet oblique, elongate, the apical side smallest; b. n. arched, going basad of t.-m.; disc. 3 with upper and lower sides practically parallel except basally.

H. 506, collected in 1891. Apechtis (e.g., A. conquisitor, 
Say) runs to this in the table of fossil species, but differs in the shape of the areolet and other characters. It is not certain that the fossil is a Pimpline, but I cannot find it among the Tryphonines or Ophiouines. The Tryphonine

Fig. 4.

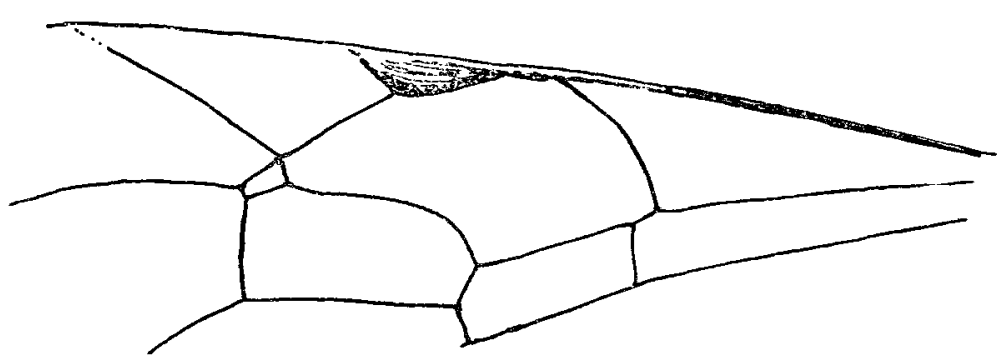

Lithupechtis (gen. nov.) fumosus, sp. n.

Acrotomus agrees in the areolet and t.-m., but is otherwise quite different. The Tryphonine Erromenus is also rather similar, with similar areolet, but the $\mathrm{m}$. and disc. 3 are quite different.

\section{Itoplectis saxosus, sp. n. (Fig. 5.)}

Anterior wing $4.3 \mathrm{~mm}$. long, clear hyaline, with dark stigma and veins, apical field very faintly dusky, stigma deep

Fig. 5.

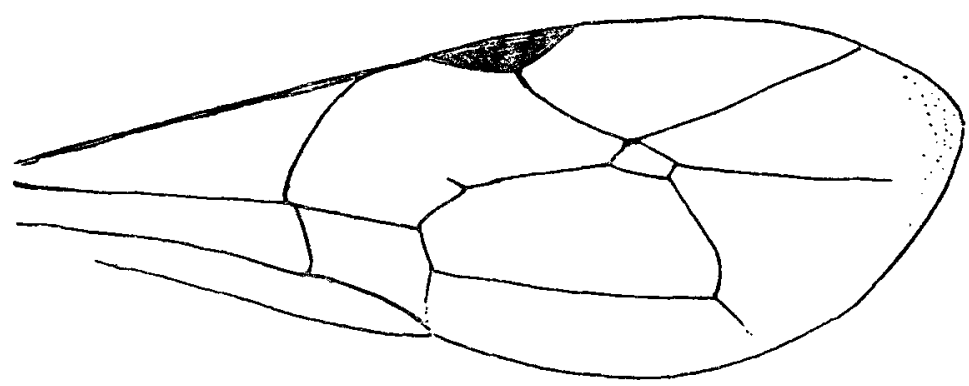

Itoplectis saxosus, sp. n.

piceous. Very similar in many respects (especially areolet) to Lithapechtis, but r. 1 is slightly curved, r. n. 1 emits a 
stump of a vein, disc. 3 is produced at end, and b. n. goes very little basad of $t$.-m.

H. 183. Collected in 1891. The rudimentary vein limiting disc. 1 on r.n. 1 is more basad than in the recent forms examined.

\section{Holomeristus (?) vectensis, sp. n. (Fig. 6.)}

Heal and thorax black. Wings hyaline, with very pale brown stigma and nervures. Anterior wing $3.5 \mathrm{~mm}$. long and very broad (about $1.3 \mathrm{~mm}$.). Stigwa large; $\mathrm{m}$. very broad (deep), r. 1 curved, r. 2 straight; areolet quadrate, very briefly petiolate above; b. n. with lower two-thirls straight, meeting t.-m., which, however, is not quite in a line with it.

Fig. 6.

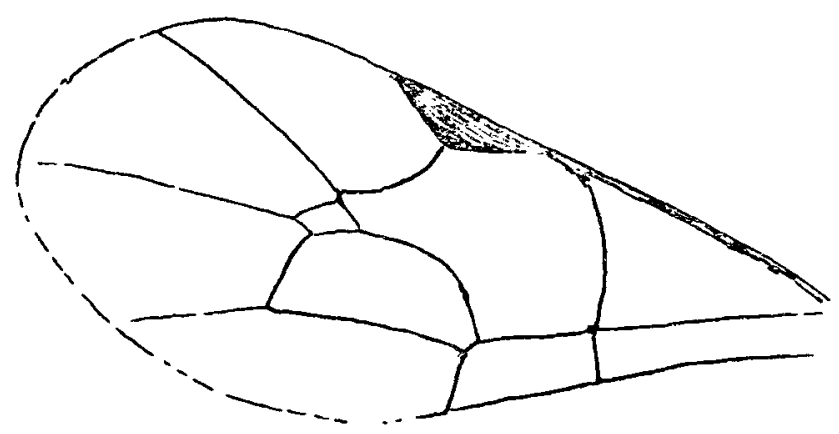

Holomeristus (P) vectensis, sp. n.

B.M., I. 9370 (B.). This was examined by Mr. C. Morley, who left a note: "either Tryphoninæ or Ophioninæ." The Ophionine genus Holomeristus agrees, except that it has the first $r$. n. uearly straight, and the marginal cell less bulying at base. It must be said, however, that the Pimpline Calliephialtes is very similar in venation, and Habropimpla is not very different.

\section{Cremastus (?) arcuatus, sp. n. (Fig. 7.)}

Length $4 \mathrm{~mm}$. ; head and thorax apparently fuscous or black ; abdomen ferruginous ; thorax small, abdomen longpetiolate. Anterior wing about $3.8 \mathrm{~mm}$. long, clear, faintly brownish in the apical field ; stigma and nervures rather dilute fuscous. Stigma large, trigonal; $\mathrm{m}$. very deep, r. 1 
gently curved, r. 2 straight, slightly curved upward at end ; b. n. curved, meeting t.-m., which is in a line with its lower part; second r. n. gently bowed outward.

lig. 7.

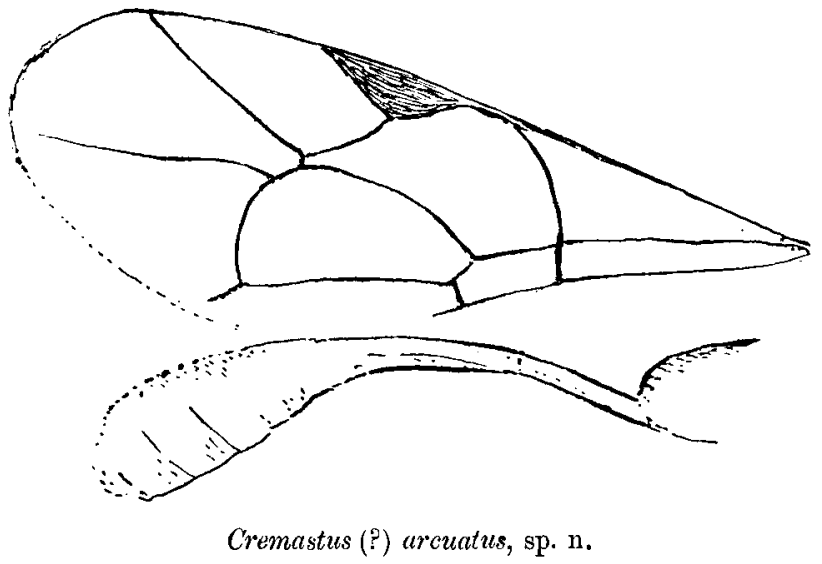

B.M., I. 9374 (B.). Resembles modern Cremastus, but that has the second b.n. straight. The venation is rather like that of the Tryphonine Exacrodus.

Polysphincta (?) atavina, sp. "1. (Fig. 8.)

Wings clear, with ferruginous veins; anterior wing slightly over $4 \mathrm{~mm}$. long. Stigma trigonal ; m. very deep

Fig. 8 .

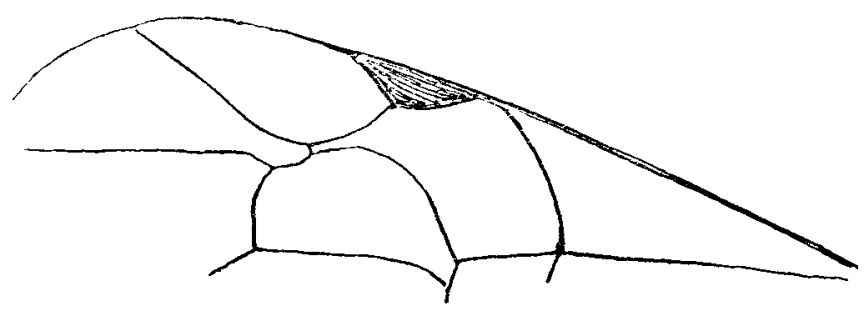

Polysphincta (?) atavina, sp. n.

(broad), the radial nervure curved, not angulate; b. n. curved, meeting the oblique t.-m., which is about in line with 
its extreme end; first r.n. strongly arched, second r. n. gently bowed outward.

H. 1036. This is certainly very like the modern Polysphincta. There is some resemblance to Promethus and Metanomalon, but it is distinet from both.

Lampronota disrupta, sp. n. (Fig. 9.)

Anterior wing $5 \mathrm{~mm}$. long; wings clear, with fuscous stigma and nervures; head and thorax black, abdomen perhaps paler; abdomen fusiform, narrowed basally, with a probably long straight ovipositor, of which not more than $1 \mathrm{~mm}$. is preserved; hind femora long and slender, length about $2 \cdot 2 \mathrm{~mm}$.; antennæ long and slender, apparently

Fig. 9.

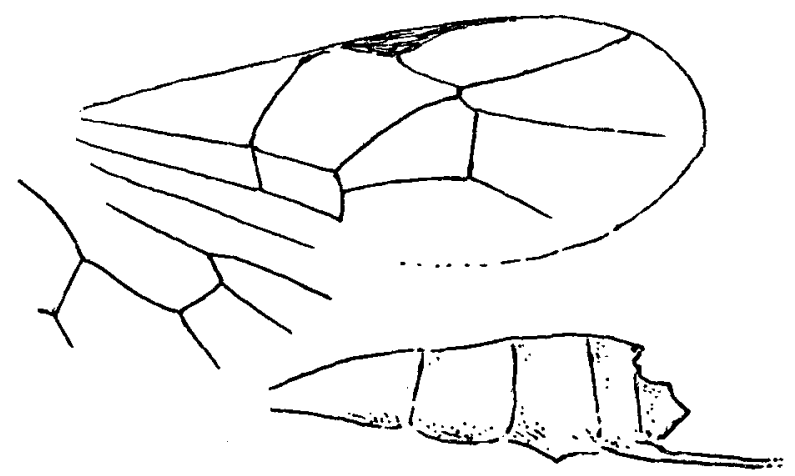

Lampronota disrupta, sp. $\mathrm{n}$.

entirely black. Marginal cell lanceolate; b. n. meeting the oblique t.-m.

B.M., I. 9711 (B.). The abdomen is separated from the thorax, but appears to belong to the same specimen; its base is near the anal angle of fore wing. This is not Bassus, but clearly Lampronota.

\section{Polyclistus (?) anglicus, sp. n. (Fig. 10.)}

Head, thorax, and antennæ black; anterior wing $3 \mathrm{~mm}$. long, dusky hyaline; stigma fuscous, nervures pale brown; m. deep, angled at t.-m., r. 2 very gently curved; b.n. strongly curved or bent; t.-m. extremely oblique. 
B.M., I. 9292 (B.). The peculiar disc. 2 is exactly that of modern Polyctistus; the thorax and abdomen also agree. The species differs from P. mansuetor, Grav., by the curved first r. $n$.

Fï. 10.

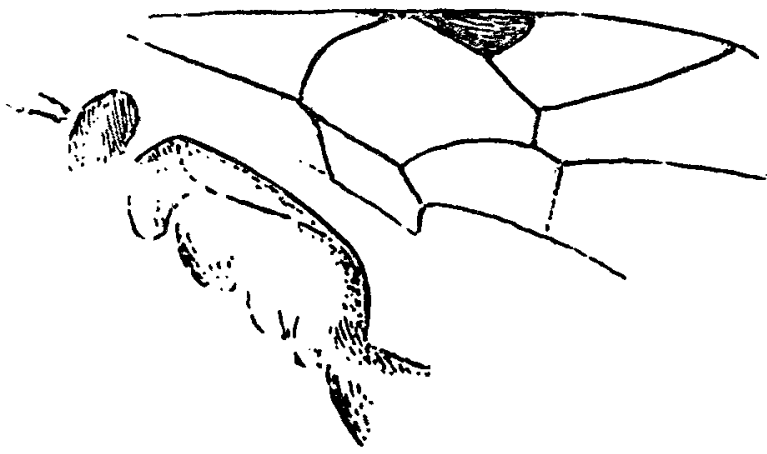

Polyclistus (?) anglicus, sp. n.

Acourtia (gen. nov.) perplexa, sp. n. (Fig. 11.)

Wing $5 \mathrm{~mm}$. long, hyaline, with dark stigma and veins. M. elongate, angled at t.-c., both sections of r. straight; b. n. straight ; t.-m. very oblique.

Fig. 11.

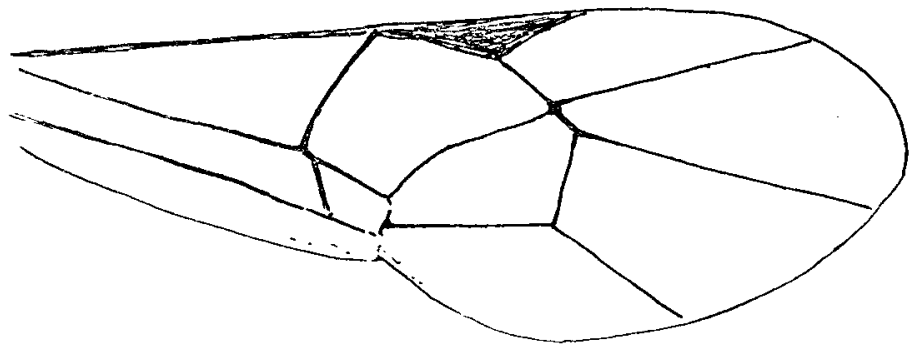

Acourtia (gen. nov.) perplexa, sp. n.

H. 858. Macrogaster differs from this by the much longer first section of radial nervure and t.-m. a little basad of b. n. ; Collyria differs by the smaller apical angle of disc. 3 , stump of vein on first r. n., and disc. 2 quite different. Accenitus runs to the same place in table of fossils, but is different, and the same may be said of Epirhyssa. 
Key to Gumet Bay Braconida.

Upper section of b. n. obsolete (disc.

1 reaching subcosta) ..........

Upper section of b. n. prevent (disc. 1 petiolate above) ..............

1. Second s.m. present ...........

Second s.m. absent (not limited

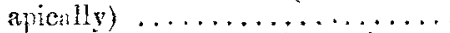

2. 1isc. 1 broadly attached to subcosta.

I)isc. 1 very narrowly attached to subcosta

3. Disc. 1 with upper angle greater than a right anrle .............

Disc. 1 with upper angle acute ....

4. A straight vein (posterior uervire) from lower coner of dise. 1 , in line with its lower side .............

No such straight vein in this position.

5. B. n. meeting t.-n.; second s.m. complete ................

B. n. not meeting t.-m. . . . . . . .

6. Disc. 1 broadly joined to second s. xl. Disc. 1 not joined to second s.m. ; its upper side strongly arched ......

7. Anterior wing about $4.3 \mathrm{~mm}$. long. . Anterior wing about $2.5 \mathrm{~mm}$. long. .

8. Second s.m. complete; upper angle of disc. 1 wide...............

Second s.m. wanting; upper angle of disc. 1 acute
1.

4.

Diospitus acourti, sp. n.

2.

Caly)toides veternus, sp. 11.

3.

Diospiloides hooley, sp. n.

Sigalphus (?) cervicalis, sp. n.

Xenarcha distracta, $\mathrm{s}_{\mathrm{p}}$, n.

5.

6.

8.

Bathystomus peritus, sp. n.

7 .

Ipobracon vectensis, sp. n.

Ipubracon micrarche, sp. n.

Phanomeris colenutti, sp. n.

Dacnusites sepultus, sp. u., and D. reductus, sp. n.

The large tropical forms, with fuliginous or maculated wings, are wholly absent from the Collection. There is no particular resemblance in the Gurnet Bay fossils to the Miocene species from Florissant. Diospilus reperlus, Brues, from Florissant, is easily separated from $D$. acourti by the second s.m. broadened below. Oligoneuroides, Brues, is unlike any of our insects.

Diospilus acourti, sp. n. (Fig. 12.)

Head and thorax black, the thorax very small, its width hardly more than half a mm.; anterior wing about $2.4 \mathrm{~mm}$. long, hyaline, faintly dusky, with pale fuscous stigma and nervures.

Stigma very large; r. 2 (beyond second s.m.) straight; second s.m. quadrate; disc. 1 very acute above; b. n. almost meeting the oblique t.-m.

B.M., I. 9071 (B.). 
Agrees excellently with modern Diospilus; dise. 1 is intermcdiate in shape between those of D. oleraceus, $\mathrm{Hal}$., and

Fig. 12.

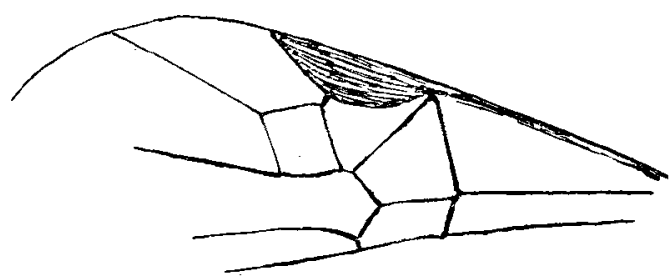

Diospilus acourti, sp. n.

D. irregularis, Wesm. In the above table, Ichneutes, Zele, and Macrocentrus would run to $D$, acorrti, but they all differ greatly in various wăys.

Calyptoides (gen. nov.) veternus, sp. n. (Fig. 13.)

Preserved in lateral profile. Head and thorax dark, thorax paler below ; abdomen petiolate, strongly curved, with a short ovipositor. Wings clear, stigma fuscous, nervures paler. Length about $2.3 \mathrm{~mm}$.; anterior wing about $2.6 \mathrm{~mm}$.

Fig. 13.
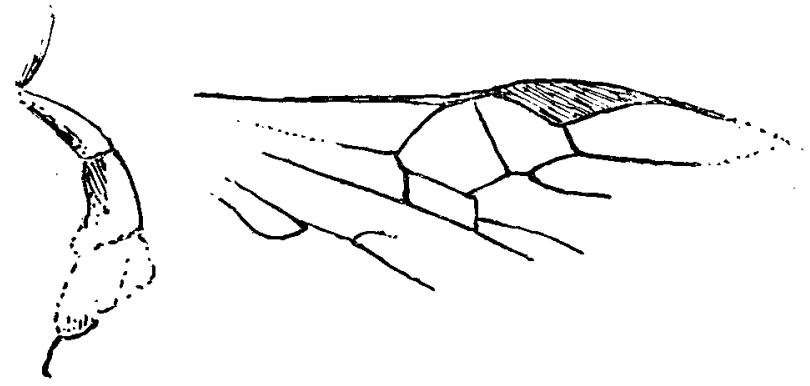

Calyptoides (gen. nov.) veternus, sp. n.

Stigma large; m. elongate; $\mathbf{r}$. obtusely angulate at $t_{.}=c$. ; b. 11. going far basad of t.-m.; disc. 1 broadly attached to subcosta; abdomen slender basally; ovipositor exserted.

B.M., I. 9722 (B.). 
Appears to be a Calyptine, differing from Eubadizon by the shape of second discoidal and of abdomen.

Diospiloides (gen. nov.) hooleyi, sp. n. (Fig. 14.)

Anterior wing about $3 \mathrm{~mm}$. long, hyaline, with dark veins. Stigma moderate; $m$. large and elongate, apical section of r. gently curved; r. 1 oblique; b. n. curved, meeting

Fig. 14.

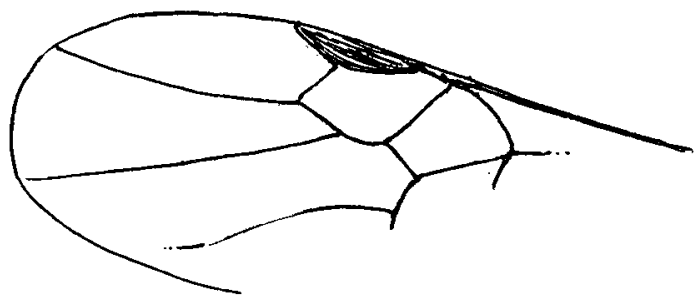

Diospiloides (gen. nov.) hooleyi, sp. n.

the very oblique t.-m.; t.-c. very oblique; first s.m. large, no second s.m.

H. 882.

I fail to find any near relative; it is perhaps related to the Diospiliuæ.

Fig. 15.

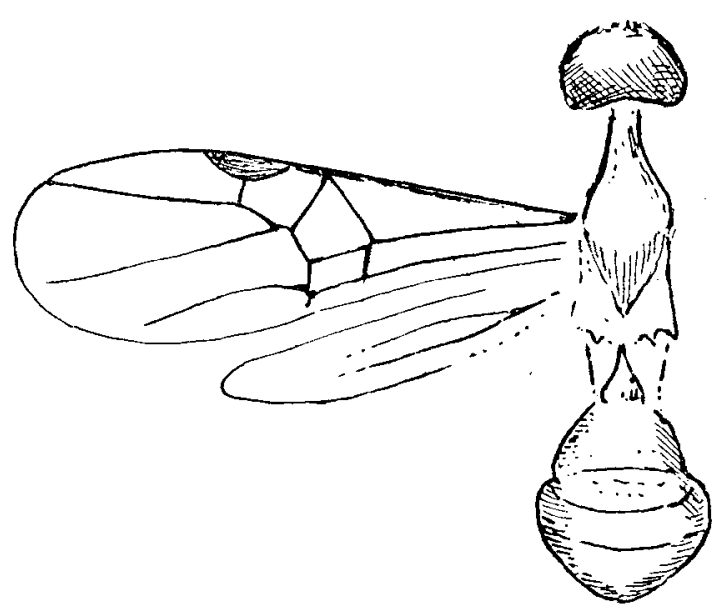

Sigalphus (?) cervicalis, sp. n. 
Sigalphus (?) cervicalis, sp. n. (Fig. 15.)

Length slightly over $2 \mathrm{~mm}$; anterior wing nearly $2 \mathrm{~mm}$. long, clear, nervures pale ferruginous. Head and prothorax dark fuscous, rest of body as preserved pale ferruginous.

Head transverse; neck elongated; thorax with posterior lateral spiues; abdomen broad; stigma robust; m. long, its angle at the oblique t.-c. little greater than a right angle, its margin beyond this straight; disc. I acutely pointed above, reaching subcosta.

B.M., I. 9199 (B.).

Probably a Sigalphus, but liffers in shape of disc. 1 and straight b. n. 'The wing shows some resemblance to Centistes, but has r. 2 curved.

\section{Xenarcha (?) distracta, sp. n. (Tig. 16.)}

Length $2 \cdot 1 \mathrm{~mm}$; anterior wing about $2 \mathrm{~mm}$., hyaline, faintly reddish; stigma dark ruto-fuscous, nervures paler.

Stigua large; m. large, r. curved, not distinctly angled

Fig. 16.

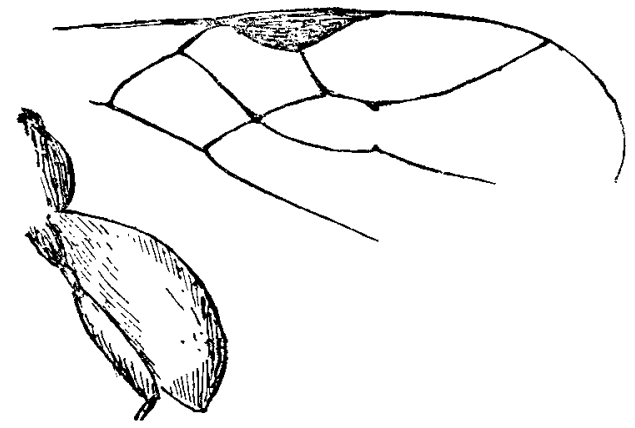

Xenarcha (?) distracta, sp. n.

at t.-c. ; second t.-c. obsolete, but represented by stumps of veins ; disc. 1 just meeting corner of second s.m., forming a cross; posterior nervure leaving lower apical corner of disc. 1 ; abdomen short and robust.

B.M., I. 9099 (B.).

From the venation this would appear to be a Hormiine, rather close to Chremylus, but that genus has the second s.m. complete and the stigma more lanceolate. Hormius agrees with the fossil in the stigma, but has second s.m. 
complete and disc. 1 broadly joins second s.m. There is also some resemblance to Xenarcha, which agrees in the form of the abdomen much better than Chremylus. The marginal cell is different from Nenarcha or Chremylus, but nearest to the former. The shape of the first s.m. is as in Chremylus. The fossil is provisionally referred to the Exothecine Yenarcha, but it probably should form a distinct genus. It may perhaps belong to Heterospilus, which it also closely resembles. It may also be compared with Ecphylus. No disposal of it is satisfactory, but I do not like to propose a new geueric name.

\section{Bathystomus (?) peritus, sp. n. (Fig. 17.)}

Anterior wing $3 \cdot 1 \mathrm{~mm}$. long; thorax with abdomen $2.2 \mathrm{~mm}$.; the thorax was apparently dark, the abdomen very pale luteous. Wings clear, stigma pale rechdish, nervures colourless or almost. The wings are large and broad, the width of anterior wing a little over $1 \mathrm{~mm}$. Abdomcu sessile, not compressed.

Fig. 17.

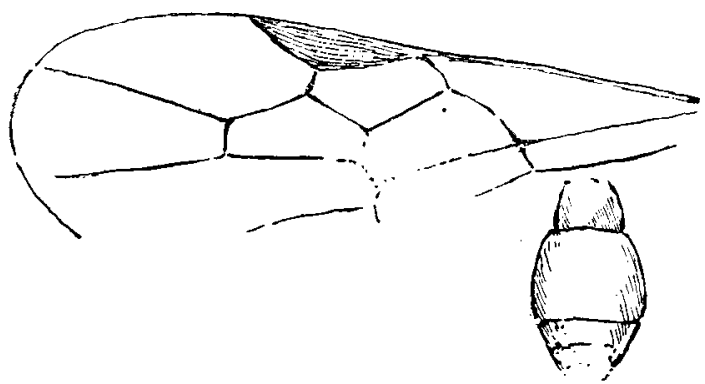

Bathystomus (?) peritus, sp. n.

Stigma large; second s.m. long, with a broad angle about middle above ; b.n. meeting t.-m., which is in a line with its lower end; disc. 1 broadly meeting second s.m.

B.M., I. 9671 (B.).

The wing agrees exactly with Bathystomus, except that in the modern genus the b. $n$. goes a considerable distance basad of t.-m. The abdonen also agrees well enough. The wing is much like that of Histeromerus, but in the latter the radial nervure is not angled at the second t.-c. Acelius and some Meteorus (M. unicolor, Westm.) run to $B$. peritus in the above table, but are actually very different. 
Ipobracon (?) vectensis, sp. n. (Fig. 18.)

Anterior wing about 4.3 long, reddish; stigma reddish. piceous, dark.

Stigna large, bulging above; r. 1 oblique ; r. 2 nearly straight; b. n. straight, meeting t.-m., which is nearly in a line with it, but a little more vertical; second s.m. large and long; disc. 1 strongly bulging above.

B.M., I. 9415 (B.).

Ipobracon is a very large genus, numerously represented in the tropics, from Brazil and Africa to Australia. It appear's possible to refer this and the following species to it, especially on account of the bulging upper side of disc. 1,

Fig. 18.

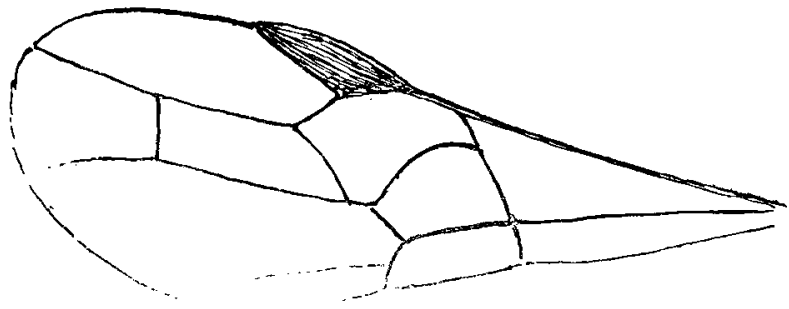

Ipobracon (?) vectensis, sp. n.

though in Ipobracon this presents an obtuse bend rather than a curve near the basal end. The hind wing, preserved in $I$. micrarche, agrees with the recent species. I. micrarche also agrees a little better than $I$. vectensis with the recent species, because disc. 1 approaches the second s.m.

Iphiaulax has the bulge in upper side of disc. 1 faintly indicated, but is not identical with the fossils. It is perhaps probable that the fossils belong to an extinct genus ancestral to Ipobracon, but this cannot be clearly diagnosed. Szépligeti treats Ipobracon as part of Iphiaulax.

$$
\text { Ipobracon (?) micrarche, sp. n. (Fig. 19.) }
$$

Anterior wing about $2.5 \mathrm{~mm}$. long, strongly reddish, with ferruginous stigma and nervures. Head and thorax black. Much smaller than $I$. vectensis, but with disc. 1 nearly touching second s.m., but apparently congeneric.

B.M., I. 9026 (B.).

Ann. \& Mag. N. Hist. Ser. 9. Vol. vii. 
Fig. 19.

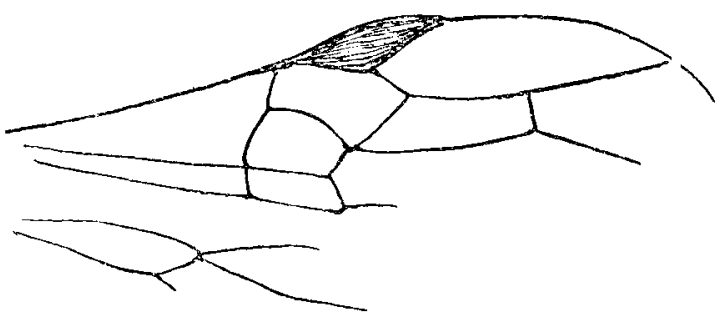

Ipobracon (?) micrarche, sp. $\mathrm{n}$.

Phanomeris (?) colen 1 tti, sp. n. (Fig. 20.)

Anterior wing $4 \mathrm{~mm}$. long ; wings clear, stigma fuscous, nervures pale brown. Head and thorax fuscous, legs paler; head small; hind femur about $1 \mathrm{~mm}$. long, only moderately stout; hind tibia + tarsus about $2.3 \mathrm{~mm}$. long.

Stigma very large, somewhat bulging; marginal cell large; terminal section of r. straight; second s.m. large; disc. 1 not reaching second s.m., its upper side straight, and its basal (b. n.) only faintly bulging.

B.M., I. 9;02 (B.). Named after Mr. G. W. Colenutt, who has long interested himself in the geology of the Isle of Wight.

Fig: 20.

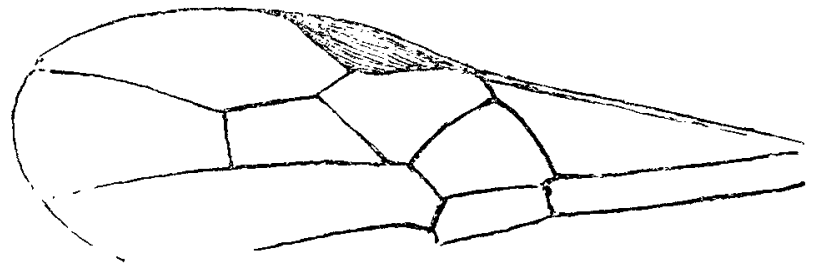

Phanomeris (?) colenutti, sp. n.

This agrees sufficiently with the living Phanomeris catenator, Hal., except that the second s.m. is not so long. There is also some resemblance to Doryctes, but that has the t.-m. more oblique. The first discoidal cell is like that of Colastes, not Doryctes, but the stigma and second s.m. are more like Doryctes. Oncophenes nearly agrees with the fossil, and the shape of disc. 1 is similar (rather more so than in Colastes), but the shape of the marginal cell differs. 
A large number of Braconid genera, run through the above table of fossils, come out at or near $P$. colenutti, but differ in various important details.

Dacnusites (gen. nov.) sepultus, sp. n. (Fig. 21.)

The genus is similar to Polemon, but the insect is smaller, with clear wings, and the radial nervure is strongly bent beyond the t.-c., making the lower part of the marginal cell bulge downward. The stigma also is somewhat differently shaped, and disc. 1 does not reach the subcosta, while the

Fig. 21.

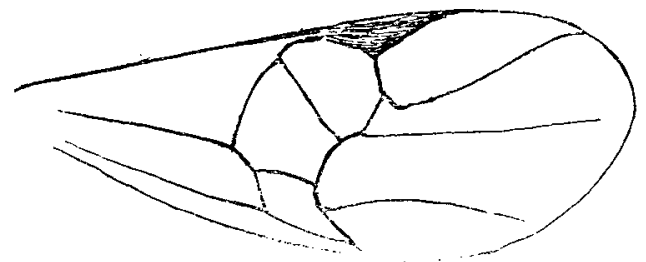

Dacnusites (gen. nov.) sepultus, sp. $\mathrm{n}$.

apex of disc. 2 is strongly produced. There is also some resemblance to Phonolexis, which agrees in having disc. 1 petiolate above.

D. sepultus, the type of the genus, has the wings perfectly clear, stigma dark fuscous, nervures paler; anterior wing $2.9 \mathrm{~mm}$. long. Antennæ and thorax black.

B.M., In. 17176 (A'C. Sm.).

Dacnusites reductus, sp. n. (Fig. 22.)

Anterior wing about $2 \mathrm{~mm}$. long, hyaline, faintly dusky in apical field; stigma and nervures frale reddish.

H. 833 .

Fig. 22.

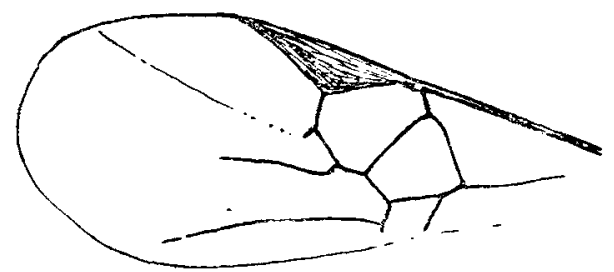

Dacnusites reductus, sp. $\mathrm{n}$. 


\section{Vespidæ.}

Polylia (?) anglica, sp. n. (Fig. 23.)

Anterior wing about $10 \mathrm{~mm}$. long, greyish hyaline, the apical third more dusky, the cxtreme apex fuscous; a fuscous cloud at end of costal cell.

\section{Fir. 23.}

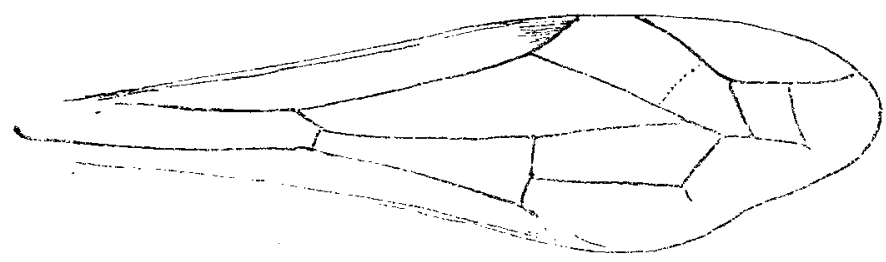

Polybia (?) anglica, sp. n.

H. 132. This agrees in general with Polybia. The dark end of costal cell is also seen in Apoica, but the course of the second $r . \mathrm{n}$. is different.

\section{Sphecidæ.}

Sceliphron (?) brevior, sp. n. (Fig. 24.)

Anterior wing about $10 \mathrm{~mm}$. long, colourless; thorax black. The small stigma, comparatively short marginal

Fig. 24 .

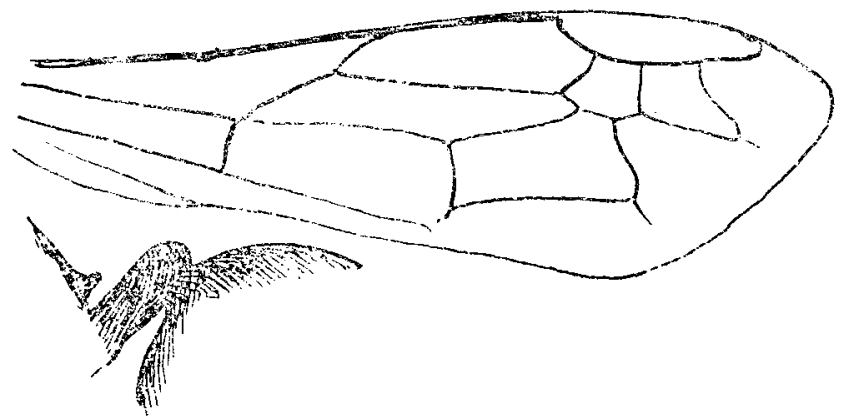

Scaliphron (?) brevion, sp. n.

cell, and very long first discoidal all occur in modern Sccliphron. The petiole is short for Sceliphron, and agrees better with Chlorion, but the wings disagree with that. 
B.M., In. 17472. This specimen has long been on exhibition in the Musenm, bnt I find that the reverse is in the Hooley collection (H.443). Doubtless both pices were collected at the same time by A'Court Smith.

\section{Bethylidæ.}

Mesitius (?) rectinervis, sp. n. (Fig. 25.)

Head and thorax yale brown; wings about $3 \mathrm{~mm}$. long, hyaline, stigma and nervures reddish brown; marginal cell

Fig. 25.

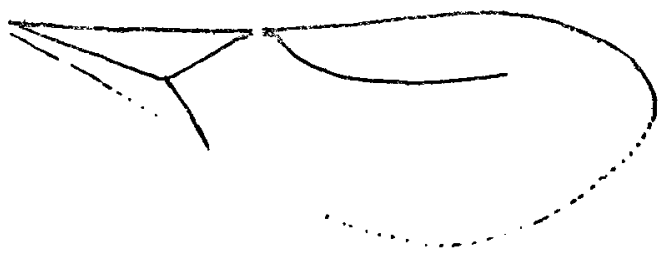

Mesitius (?) rectinercis, sp. 11 .

widely open at end; apical margin of second basal cell very oblique, pointed.

B.M., I. 9352 (B.). Differs from modern Mesitius in the shape of the second basal cell.

\section{Scelionidæ.}

Macroteleia veterna, sp. 11. (Fig. 26.)

Length about $4.5 \mathrm{~mm}$., the ablomen greatly elongated and tapering. Dark fuscous, with clear wings, anterion wing about $1.5 \mathrm{~mm}$. long.

B.M., In. 17262 (A’C. Sm.).

Fig. 26.

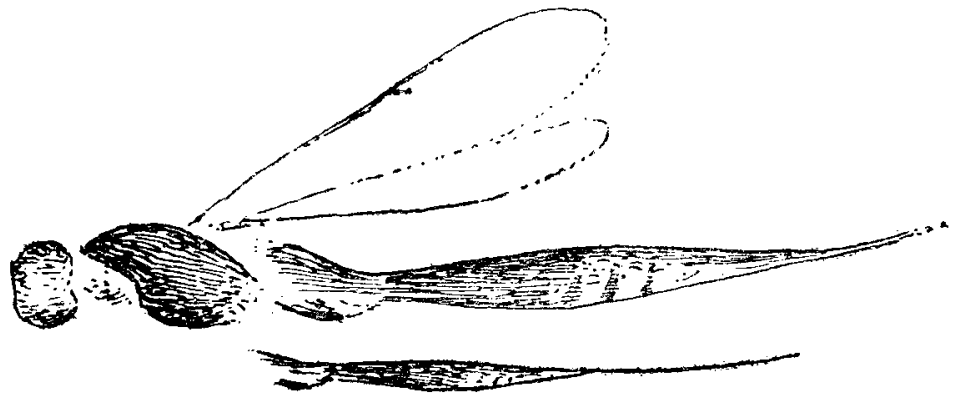

Macroteleia veterna, sp. $\mathrm{n}$. 


\section{Belytidæ.}

Lithobelyta (gen. nov.) reducta, sp. n. (Fig. 27.)

The genus resembles Belyta, but the stigma and marginal cell are absent. The head is broad, and shaped as in Belyta; the thorax is finely rugose, or rather transversely aciculate or granular.

Fig. 27.

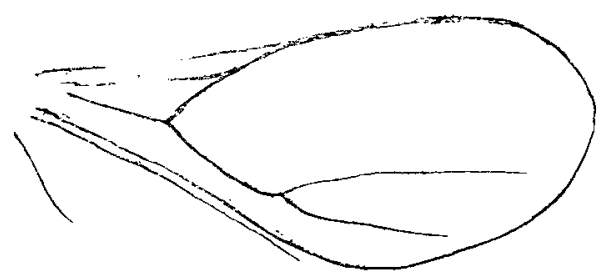

Lithobelyta (gen. nov.) reducta, sp. n.

Thorax pitch-black; wings perfectly clear, anterior wing about $2 \cdot 3 \mathrm{~mm}$. long, principal nervures brown; hind wing with no visible venation.

B.M., In. 17091 (A'C. Sm.).

$$
\text { Miota (?) strigata, sp. n. (Fig. 28.) }
$$

Pure black, with small rounded head and slender petiolate abdomen; anterior wing hardly $2 \mathrm{~mm}$. long, reddish hyaline, principal nervures dark brown.

Fig. 28.

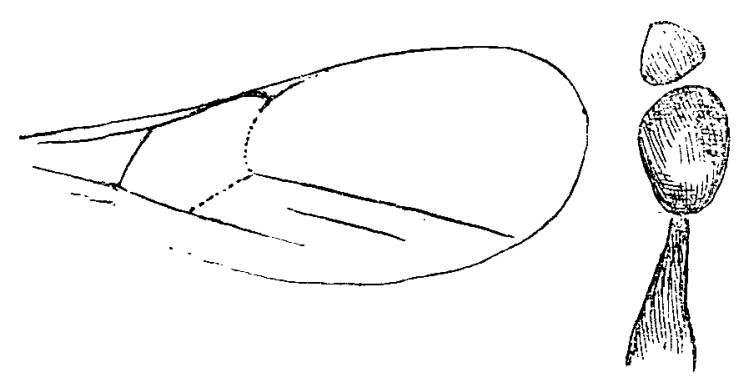

Miota (?) strigata, sp. n. 
B.M., I. 9312 (B.). Certainly very near to modern Miota, but perhaps a distinct genus, with the venation more complete. It is also very similar to Acropiesta.

\section{Zygota (?) filicornis, sp. n. (Fig. 29.)}

$\delta$. Head, thorax, and antennæ piceous; head elongated, broader behind; thorax robust; antennæ very long and filiform, length about $2 \cdot 3 \mathrm{~mm}$.; wings hyaline, anterior wing about $2 \mathrm{~mm}$. long.

Fig. 29.

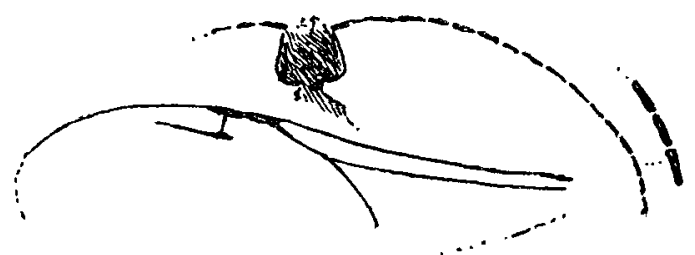

Zygota (?) flicomis, sp. n.

B.M., I. 9269 (B.). Differs from modern $Z$ Zygota by the elongate head and very long antennæ. The venation exactly agrees with the Diapriid Idiotypa, but the antennis are quite different.

\section{Cynipidæ.}

Andricus vectensis, sp. n. (Fig. 30.)

Length about $3 \mathrm{~mm}$.; anterior wing about $2.7 \mathrm{~mm}$. long, hyaline, with dark veins.

Fig. 30 .

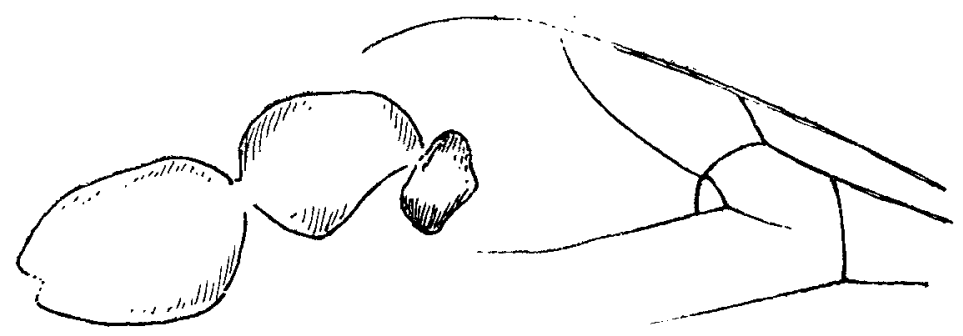

Andricus vectensis, sp. n. 
B.M., I. 8923 (B.). Agrees with modern Andricus sufficiently well, and is presumably congeneric.

\section{Rhodites vetus, sp. в. (Fig. 31.)}

Wing about $3.1 \mathrm{~mm}$. long, with dark veins. The venation agrees with that of modern $R$ hodites, even to the thickening of the t.-c. representing all that is left of the second s.m.

Fig. 31.
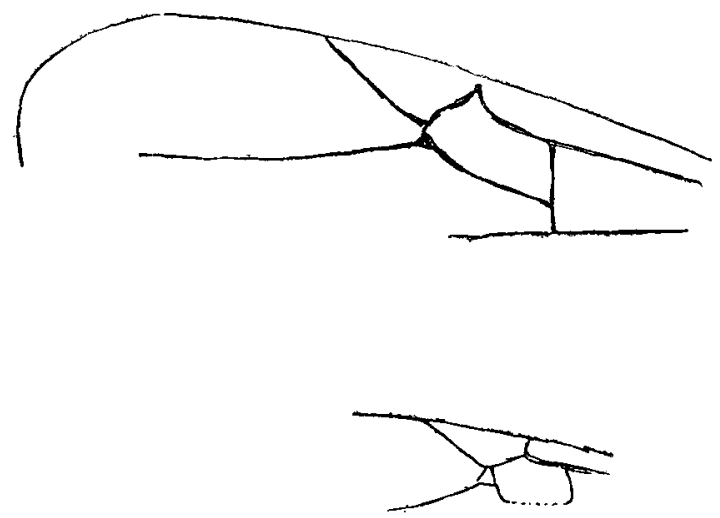

Rhodites vetus, sp. $\mathrm{n}$.

Fig. 32

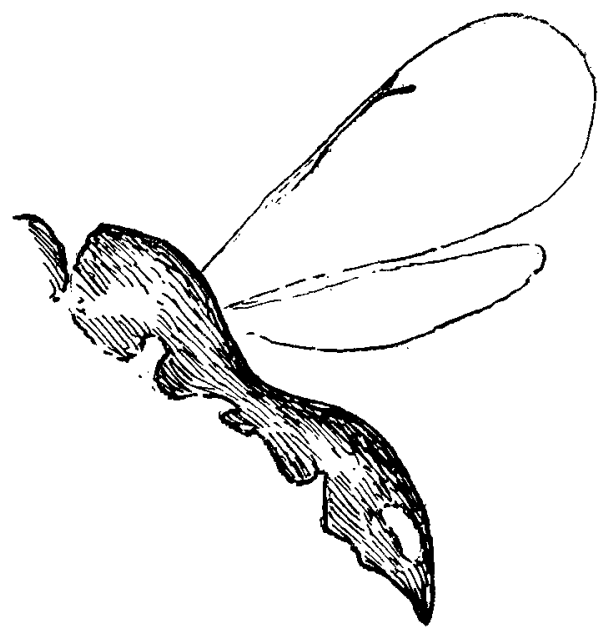

Pteromalus (?) vectensis, sp. $\mathrm{n}$. 
H. 701. The genus Rosa, on which this should have produced galls, is well known from the Miocene of Florissant, and doubtless existed much earlier. More dubious fossils ascribed to Rosa ( $R$. lignitum, Heer, $R$. dubia, Weber, $R$. nausicaës, Weber) have been described from the Oligocene of Europe.

\section{Pteromalidæ.}

Pteromalus (?) vectensis, sp. n. (Fig. 32.)

Head, thorax, and abdomen deep black as preserved; length about $2.3 \mathrm{~mm}$. ; anterior wing about $1.8 \mathrm{~mm}$. long, broad, pale brown, with dark fuscous or black stigmatic vein, which is shorter than in the Florrisant fossil $P$. exanimis, Brues.

B.M., I. 9472 (B.).

II.-Further Notes on Platypodidæ and Scolytidæ collected by Mr. G. E. Bryant and others. By Lt,-Col. WinN SAMPSON, F.E.S.

Is my previous paper, published in this Magazine (Sept. 1919), the following corrections are necessary, viz.:-On page 105 the last two lines should be deleted, as also the last tive lines on page 110 and the first three lines on page 111.

'I'he tollowing should be added to the description of Cryphalus corpulentus:-The apex of the seventh abdominal segment in the $\delta$ is provided with three pointed teeth, the centre one shorter than the other two.

This species resembles stephanorhopalus nulodori, Hopk., but has only three abdominal teeth, and the antennal club is distinctly sutured; it may, however, have to be removed into that genus.

\section{Family Platypodidæ.}

Genus Platrpus, Chap.

Platypus secretus, sp. n.

§. Brown. Front almost flat and subopaque, rugose, with longitudinal ridges and a short, central, narrow depression, densely hairy towards the vertex, a transverse row of yellow hairs over the mouth; the antennæ inserted close to the anterior edge of the eyes. 